http://doi.org/10.35784/iapgos.2659

\title{
OVERVOLTAGE PROTECTION OF PV MICROINSTALLATIONS - REGULATORY REQUIREMENTS AND SIMULATION MODEL
}

\begin{abstract}
Klara Janiga
Lublin University of Technology, Faculty of Electrical Engineering and Computer Science, Lublin, Poland

Abstract. In low-voltage power networks with a large share of distributed energy sources, the phenomenon of overvoltage is increasingly observed. Although it may be desirable to raise the voltage value downstream of the network, in some cases the upper allowable voltage limit is exceeded. The method of eliminating voltage rises commonly used in the Polish power system is the installation of overvoltage protections, disconnecting the source from the grid. Such action reduces the profitability of prosumer installations, discouraging future potential investors. It turns out, however, that this is not the only disadvantage of such a solution. Sudden and uncoordinated disconnections and reconnections of more energy sources cause abrupt voltage changes that negatively affect the voltage conditions in the network. The aim of the paper is to present the operating algorithms of a standard overvoltage relay used in inverters of photovoltaic microinstallations. These algorithms - described in standards and national regulations - were tested in a typical inverter used in public low-voltage networks and implemented in the created simulation model of the relay. The described tests will be used for further work to demonstrate the need to coordinate the operation of overvoltage protections or replace them with other measures to improve voltage conditions in the grid with high share of photovoltaic sources.
\end{abstract}

Keywords: overvoltage protection, distributed power generation, photovoltaic systems, power distribution lines

\section{ZABEZPIECZENIE NADNAPIECCIOWE MIKROINSTALACJI PV - WYMAGANIA I MODEL SYMULACYJNY}

Streszczenie. W sieciach elektroenergetycznych niskiego napięcia z dużym udziatem rozproszonych źródet energii coraz częściej obserwuje się zjawisko podskoku napięcia. Choć samo podniesienie wartości napięcia $w$ gtębi sieci może być pożadane, to jednak w niektórych przypadkach dochodzi do przekroczenia górnej dopuszczalnej granicy napięciowej. Powszechnie stosowanym w polskim systemie elektroenergetycznym sposobem eliminacji podskoków napięcia jest instalowanie zabezpieczeń nadnapięciowych, wyłaczajacych źródło z sieci. Działanie takie obniża opłacalność instalacji prosumenckich, zniechęcając przyszłych potencjalnych inwestorów. Okazuje się jednak, że nie jest to jedyna wada takiego rozwiąania. Nagłe i nieskoordynowane wytaczenia i ponowne załaczenia większej liczby źródel energii powoduja skokowe zmiany napięcia, które negatywnie wptywaja na warunki napięciowe $w$ sieci. Celem artykulu jest zaprezentowanie algorytmów działania standardowego przekaźnika nadnapięciowego stosowanego $w$ falownikach mikroinstalacji fotowoltaicznych. Algorytmy te - opisane $w$ normach i krajowych przepisach - przetestowano $w$ typowym falowniku stosowanym $w$ publicznych sieciach niskiego napięcia oraz zaimplementowano $w$ utworzonym modelu symulacyjnym przekaźnika. Opisane badania postuża do dalszych prac, mających wykazać konieczność koordynacji działania zabezpieczeń nadnapięciowych lub zastapienia ich innymi środkami poprawy warunków napięciowych w sieci z dużym nasyceniem fotowoltaika.

Slowa kluczowe: zabezpieczenie nadnapięciowe, rozproszona generacja, systemy fotowoltaiczne, elektroenergetyczne sieci niskiego napięcia

\section{Introduction}

The appearance of distributed energy sources in the lowvoltage (LV) network brings many benefits to both the installation owner and the distribution system operator (DSO). Prosumer installations - which in Polish conditions are mostly photovoltaic (PV) microinstallations - generate additional power in the grid, which allows to cover the growing demand for electricity. Thus, it reduces the need to build new units in conventional power plants, replacing them with emission-free sources. The production of electricity close to the place of its consumption allows to reduce power losses in the network and also - in some situations - to improve the quality parameters of energy, for example by reducing voltage drops.

Although the increase in the number of PV microinstallations connected to the LV grid is a desirable phenomenon, it also has some negative effects. One of the most significant effect is the increase in the voltage value (so-called "overvoltage" or "voltage boosting") $[1,2,4]$. This phenomenon occurs when the power generated exceeds the demand in the given network. Such a situation usually takes place only for a part of the day, in networks with a large share of PV installations, when high insolation is accompanied by low local power demand. A measure commonly used in the national power system to prevent overvoltage is the use of overvoltage protections implemented in PV installation inverters. These protections disconnect the generator when the voltage at the connection point of the PV source is too high, which, although it causes the intended voltage reduction, is also associated with a decrease in the profitability of the installation for the owner due to a break in energy production. You can also expect other negative effects related to the uncoordinated operation of many protections of this type, causing sudden voltage changes. The research described in this paper was intended to explore the topic of algorithms for the operation of standard overvoltage relays used in PV inverters. These studies are the starting point for further work to show the negative impact of uncoordinated operation of overvoltage protections on the stability of voltage conditions in the network.

The paper is structured as follows: section 1 provides an overview of the standards and national regulations for the operation and setting of overvoltage relays in low-voltage grid-connected PV microinstallations. Section 2 presents the results of tests of the inverter in terms of the operation of the overvoltage protection. Section 3 contains a description of the created simulation model of overvoltage protection. Section 4 describes the most important conclusions and further research directions.

\section{Overvoltage protection in PV installations - requirements of standards and regulations}

A photovoltaic microinstallation can be defined - according to the Renewable Energy Sources Act [5] - as an installation with a total electric power of up to $50 \mathrm{~kW}$ connected to the power grid with a rated voltage lower than $110 \mathrm{kV}$. These installations are included in the group of type A power generating modules (PGM) according to the division introduced in Commission Regulation (EU) 2016/631 of April 14, 2016 establishing the EU network code (so-called the NC RfG - Network Codes Requirements for Generators) [6 ]. The provisions of this regulation as well as other supplementary national regulations are compiled in detail in the documents issued by individual distribution network operators, such as "The Instruction of Distribution Network Operation and Maintenance (IRiESD)" (e.g. [7]) or the "Set of requirements for type A power generating modules, including microinstallations "(e.g. [12]). Although each of the DSOs published their own version of the above documents, the provisions contained therein are consistent throughout the country. 
As regards equipping microinstallations with protection against voltage increase, the domestic DSOs specified the requirements contained in table 1 .

Table 1. Required settings of protection against voltage increase in microinstallations connected to the LV grid [12]

\begin{tabular}{|c|c|c|c|c|}
\hline Protection type & \multicolumn{2}{|c|}{ Trip value } & $\begin{array}{c}\text { Maximum } \\
\text { disconnect } \\
\text { ion time }\end{array}$ & $\begin{array}{c}\text { Minimum } \\
\text { operate } \\
\text { time }\end{array}$ \\
\hline Over-voltage - stage $1 *$ & $1.1 U_{\mathrm{n}}$ & $253.0 \mathrm{~V}$ & $3.0 \mathrm{~s}$ & - \\
\hline Over-voltage - stage 2 & $1.15 U_{\mathrm{n}}$ & $264.5 \mathrm{~V}$ & $0.2 \mathrm{~s}$ & $0.1 \mathrm{~s}$ \\
\hline $\begin{array}{l}* \\
10 \text {-minute mean value, according to EN 50160. Detailed requirements } \\
\text { for the measurement of the mean value are included in the Polish standards. }\end{array}$ \\
\hline
\end{tabular}

The overvoltage protection should be integrated with the inverter and operate in two stages. The second stage of protection is based on the determination of the RMS voltage value, and its almost instantaneous activation takes place when the value of $1.15 U_{\mathrm{n}}$ is exceeded. The first stage of protection should respond to a 10-minute mean value, determined in accordance with EN 50160:2010 [8] and national standards. The PN-EN 50549-1:2019-02 [9] and the earlier PN-EN 50438:2014-02 [10] standards specify the method of determining the criteria values of protection. According to the above standards, RMS values should be set as "true r.m.s." or as fundamental component-values. Determining the 10-minute mean value should meet the following requirements:

- comply with 10 min aggregation of EN 61000-4-30, class S;

- be based on the calculation of the square root of the arithmetic mean of the squared input values over $10 \mathrm{~min}$;

- a moving window shall be used (in deviation from EN 61000-4-30);

- the calculation of a new 10-min value at least $3 \mathrm{~s}$ is sufficient, which is then be compared with the trip value.

The 61000-4-30 standard [11] defines the method of aggregation in the 10-minute interval for class $\mathrm{S}$. The basic time for measuring the voltage value should be a 10-period interval (for a system with a frequency of $50 \mathrm{~Hz}$ ). Determining the 10-minute mean value should therefore be based on the RMS values determined in the intervals of $0.2 \mathrm{~s}$ (time of 10 periods).

Automatic reconnection (after tripping of the interface protection) can take place when the voltage at the connection point is kept within the limits of $0.85 U_{\mathrm{n}} \leq U \leq 1.1 U_{\mathrm{n}}$ for the minimum observation time equal to 60 seconds.

\section{Tests of the operation of overvoltage protection in the PV inverter}

To test the overvoltage protection, an inverter of a three-phase PV microinstallation of one of the buildings of Lublin University of Technology (LUT) was selected. This installation consists of 60 photovoltaic panels installed on the roof of the Centre for Innovation and Advanced Technologies of LUT. The total power of the microinstallations is $15 \mathrm{~kW}$. The SMA Sunny Tripower STP 150000TL-10 inverter used in the installation is a typical device that allows the connection of photovoltaic panels to the public low-voltage network. The inverter is equipped by the manufacturer with the required set of protections, including protection against voltage increase, the settings of which are presented in the table 2 . These settings result from the selected country standard setting - compliance with EN50438 has been selected.

The test stand for testing the operation of overvoltage protection has been equipped with a three-phase autotransformer enabling smooth voltage regulation. The change of voltage in the autotransformer allows to reproduce the variability of voltage conditions in the network and lead to the situation of exceeding the set voltage thresholds, which should result in activation of the protection. Electrical parameters, such as voltages at the inverter connection point and generated power, were recorded on a HIOKI 3196 power quality analyzer with a recording time resolution of 15 seconds.
Table 2. Overvoltage protection settings in the tested SMA inverter

\begin{tabular}{|c|c|c|}
\hline Function & Setting & Time delay \\
\hline $\begin{array}{c}\text { Voltage increase } \\
\text { protection }\end{array}$ & $253.00 \mathrm{~V}$ & - \\
\hline $\begin{array}{c}\text { Lower maximum } \\
\text { threshold }\end{array}$ & $264.50 \mathrm{~V}$ & $200 \mathrm{~ms}$ \\
\hline
\end{tabular}

To illustrate the operation of the 1st stage of overvoltage protection (delayed operation - based on the measurement of a 10-minute value), two test scenarios were selected. In the first scenario, the rated voltage was maintained for more than 10 minutes, and then the voltage was increased by means of an autotransformer to a value exceeding the protection activation threshold (approx. 258 V). After activation of the protection, the voltage was lowered again to the rated value so that the source could reconnect. The waveform of voltage and power generated in a microinstallation is shown in figures 1 and 2 .

From the data recorded by the analyzer, one can read the protection tripping time and the generator reconnection time. The tripping time, measured from the moment of exceeding the threshold of $1.1 U_{\mathrm{n}}(253 \mathrm{~V})$ to the impulse for switching off the generation, was 7:45 minutes, while the time to full disconnection of the source (generated power equal to zero) was 8:15 minutes. The reconnection time, measured from the voltage drop below the $1.1 U_{\mathrm{n}}$ threshold to the moment when the source generates power, was approx. 1:30-2:00 minutes.

The second test scenario is similar, but the value maintained before the protection is triggered is higher - instead of $230 \mathrm{~V}$, the value was set to $237 \mathrm{~V}$. After the time exceeding 10 minutes, this value was increased again to the value of approx. $258 \mathrm{~V}$ If the protection algorithm complies with the standard and by the 10-minute average value, this protection should operate in a shorter time than in scenario 1. Recorded waveforms and designated times are shown in figure 3 .
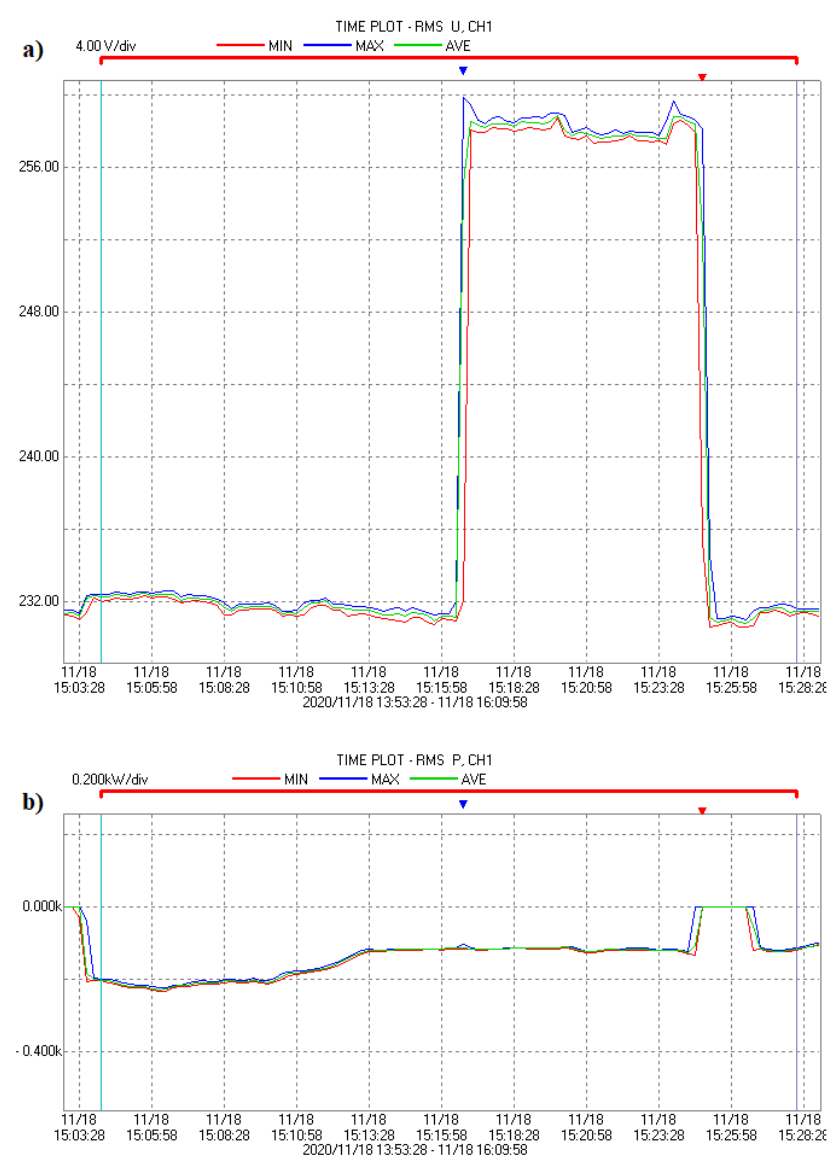

Fig. 1. Waveforms recorded in the analyzer for test scenario 1: a) measured voltage, b) generated active power (negative values mean power fed back to the network) 


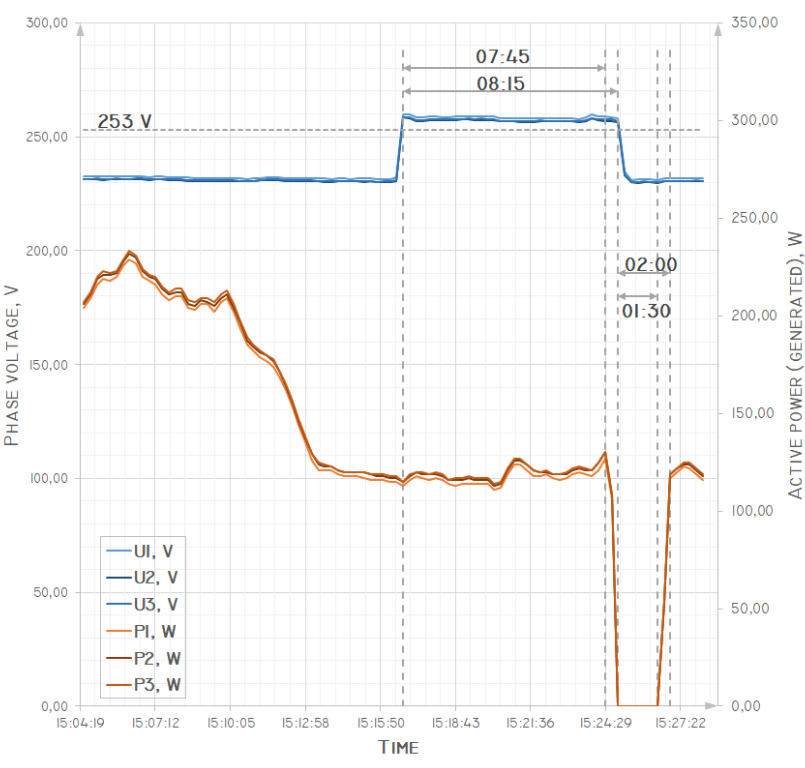

Fig. 2. Voltage and power waveforms for scenario 1 with marked test results protection tripping time and source reconnection time

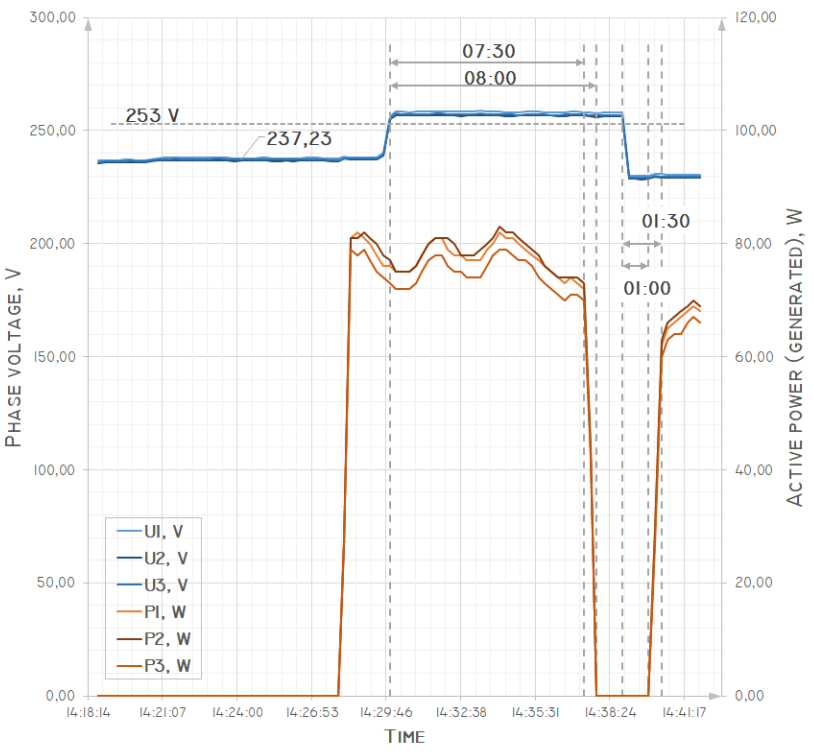

Fig. 3. Voltage and power waveforms for scenario 2 with marked test results protection tripping time and source reconnection time

In scenario 2, as expected, the protection tripping times were shorter. The tripping time (from the moment of exceeding the set value of $1.1 U_{\mathrm{n}}$ to the impulse for switching off the generation) was 7:30 minutes, while the time until the complete disconnection of the source was 8:00 minutes. The reconnection time, measured from the voltage drop below the $1.1 U_{\mathrm{n}}$ threshold to the moment when the source generates power, was approx. 1:00-1:30 minutes. The results are burdened with a relatively large measurement error due to the recording time resolution of 15 seconds. The conducted tests - described above in the two scenarios and the others, not described in this paper - allowed to determine that the speed of the protection operation is influenced not only by the voltage value after exceeding the threshold of $1.1 U_{\mathrm{n}}$, but also by the preceding values, which may indicate that the protection responds to 10-minute mean value in a moving window, i.e. in accordance with the standard. Also, the second stage of protection turned out to be compliant with the requirements of the standard - after setting the autotransformer to a value exceeding $1.15 U_{\mathrm{n}}$, the protection immediately turned off the generator.

\section{Simulation model of overvoltage protection of PV microinstallations}

The creation of a fully functional protection model for the purposes of simulation is key to show various scenarios of operation, but above all to show the interaction of many such protection systems installed in the network with a large number of prosumer installations. The overvoltage relay model was made in the DIgSILENT PowerFactory software, using the DSL language (DIgSILENT Simulation Language) enabling modeling time continuous controls and processes.

The operation of the relay model is based on the measurement of instantaneous voltage values at the connection point (POC) of the PV source. These values are sampled at the specified sampling rate. From the thus obtained discrete signal, the RMS value is determined at 10-period intervals ( 0.2 seconds). This value is then aggregated for 10 minutes according to the standard [11] and the 10-minute average value is determined by the moving window method with a width of 600 seconds. The mean value is calculated as the square root of the arithmetic mean of the squared input values over $10 \mathrm{~min}$. The correctness of the model was verified by trying to reproduce the conditions of the laboratory tests described in section 2. Therefore, the simulations considered a simple system consisting of an MV/LV transformer enabling the change of the voltage value in the network, and the low-voltage line supplied from it. A three-phase PV source with a rated power of $50 \mathrm{~kW}(\cos \varphi=1)$ with an overvoltage relay and a load of $50 \mathrm{~kW}$ was connected at the end of the line.

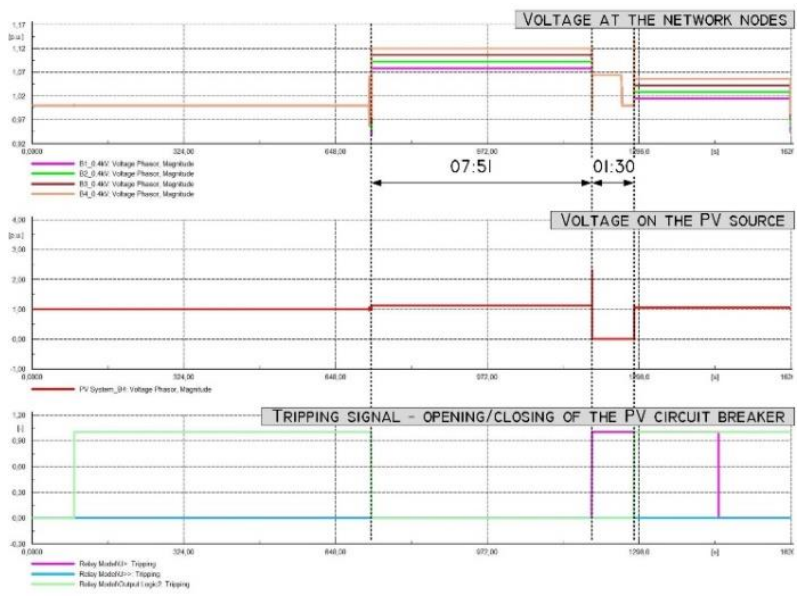

Fig. 4. Simulation results (scenario 1) - overview
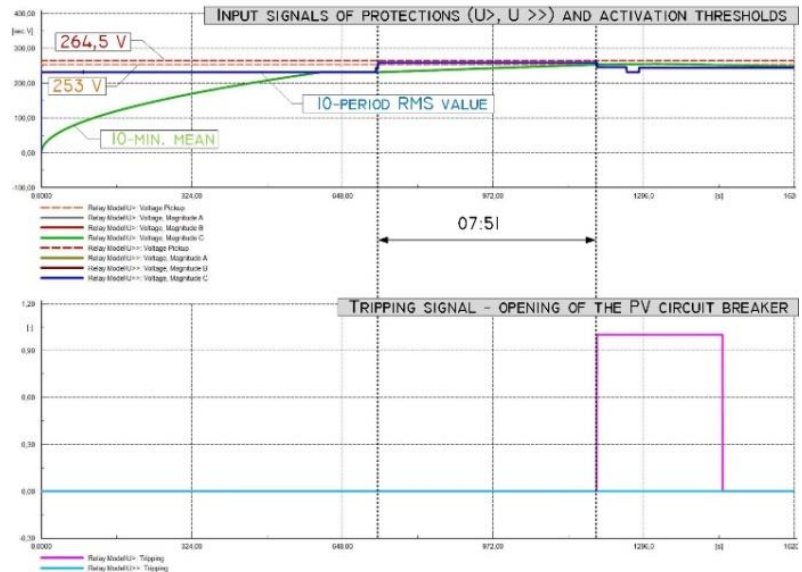

Fig. 5. Simulation results (scenario 1) - operation of overvoltage protection

The aim of the simulations was to recreate the laboratory test scenarios presented in section 2. Voltage changes at the point of connection were obtained by changing the transformer tap, changing the value of the generated power and the load power. The schedule of the two simulation scenarios is presented in the form of table (table 3 ). 
Table 3. Simulation scenarios for tests of 1st stage overvoltage protection (U>)

\begin{tabular}{|c|c|c|}
\hline Simulation time & Scenario 1 & Scenario 2 \\
\hline $0-12: 00 \mathrm{~min}$ & $\begin{array}{c}\text { The voltage at the POC } \\
\text { is kept at 230 V }\end{array}$ & $\begin{array}{c}\text { The voltage at the POC } \\
\text { is kept at 237 V }\end{array}$ \\
\hline 12:00-12:05 & $\begin{array}{c}\text { Gradual increase in voltage } \\
\text { to 258 V }\end{array}$ & $\begin{array}{c}\text { Gradual increase in voltage } \\
\text { to 258 V }\end{array}$ \\
\hline Unknown & $\begin{array}{c}\text { Protection stage 1 (U>) } \\
\text { triggering }\end{array}$ & $\begin{array}{c}\text { Protection stage 1 (U>) } \\
\text { triggering }\end{array}$ \\
\hline 21:00 min & $\begin{array}{c}\text { Lowering the voltage } \\
\text { to the rated value }\end{array}$ & $\begin{array}{c}\text { Lowering the voltage } \\
\text { to the rated value }\end{array}$ \\
\hline Unknown & $\begin{array}{c}\text { Reconnection } \\
\text { of microinstallations }\end{array}$ & $\begin{array}{c}\text { Reconnection } \\
\text { of microinstallations }\end{array}$ \\
\hline
\end{tabular}

The recorded waveforms for the simulation scenario 1 are shown in figures 4 and 5 . The protection stage 1 was triggered at 19:56 minutes. Therefore, the tripping time, measured from exceeding the threshold of 1.1 $U_{\mathrm{n}}$ (at 12:05 $\mathrm{min}$ ) to the occurrence of the signal for tripping the circuit breaker, was 7:51 minutes.

For scenario 2 of the simulation, the waveforms presented in figures 6 and 7 were recorded. The protection stage 1 was activated at 19:44 minutes. The tripping time, measured from exceeding the threshold of 1.1 $U_{\mathrm{n}}$ (at 12:05 min) to the occurrence of the signal for tripping the circuit breaker, was therefore 7:39 minutes. The reconnection time in the simulation resulted from the introduced delay setting (90 seconds) and was the same for both scenarios.

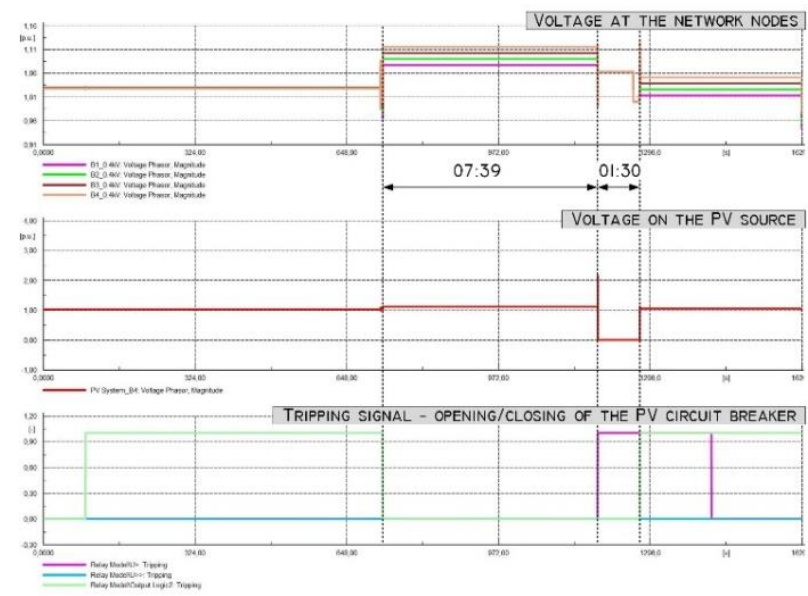

Fig. 6. Simulation results (scenario 2) - overview

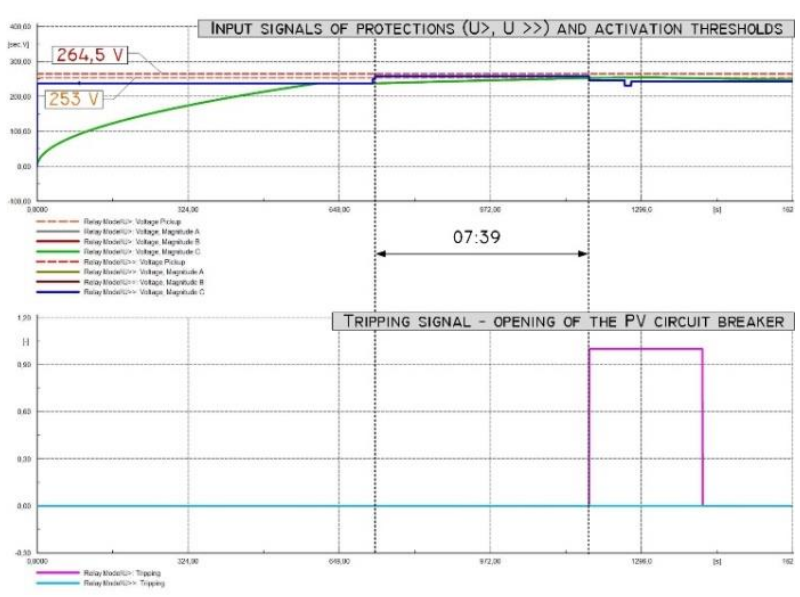

Fig. 7. Simulation results (scenario 2)-operation of overvoltage protection

Table 4. Comparison of the results of laboratory tests of the SMA inverter protection and simulation results on the protection model in PowerFactory

\begin{tabular}{|c|c|c|}
\hline & $\begin{array}{c}\text { Tripping time ( U>) } \\
\text { in the SMA inverter }\end{array}$ & $\begin{array}{c}\text { Tripping time ( U>) } \\
\text { in the PowerFactory model }\end{array}$ \\
\hline Scenario 1 & $7: 45 \mathrm{~min}$ & $7: 51 \mathrm{~min}$ \\
\hline Scenario 2 & $7: 30 \mathrm{~min}$ & $7: 39 \mathrm{~min}$ \\
\hline
\end{tabular}

The simulations did not take into account additional delays in the operation of the protection occurring in the actual system. The comparison of the obtained tripping times of the protection in the laboratory test and in the simulation - is included in table 4.
The results confirm the compliance of the simulation model with the requirements of standards and regulations, as well as with the algorithm of protection operation in a typical inverter.

\section{Summary}

The paper presents the requirements of national regulations and standards regarding the operation of overvoltage protections integrated with the inverter of photovoltaic microinstallations. The functionality of this type of protection has been tested in laboratory tests, on the example of a typical inverter used in microinstallations connected to public low-voltage distribution networks. A simulation model was also built in the PowerFactory software, and its correctness was verified in the simulations. The results obtained in the simulations are consistent with the results obtained from the tests of the SMA inverter, therefore it can be concluded that the model complies with both the regulations and the actual operation of the overvoltage relay.

The simulation model will be used in further research aimed at indicating the potential negative effects of the operation of a greater number of such protections in networks with a large share of PV microinstallations. Lack of coordination of overvoltage protections (limiting the power delivered to the network to zero) may result in negative dynamic phenomena that threaten the stability of voltage conditions in the network. The introduction of a uniform system enabling the coordination of protections operations could prevent such phenomena. In addition, the introduction of such a system will certainly be facilitated by the provisions of the NC RfG code [6, 12], which impose on the manufacturers of inverters the need to ensure the possibility of remote disconnection of microinstallations above $10 \mathrm{~kW}$. In order to prevent the necessity to disconnect microinstallations, it is advisable to first implement voltage regulation methods so as not to exceed the permissible limits [3]

\section{References}

[1] Appen J. et al.: Time in the sun: The challenge of high PV penetration in the German electric grid. IEEE Power and Energy Magazine 11(2), 2013, 55-64 [http://doi.org/10.1109/MPE.2012.2234407].

[2] Hashemi S., Østergaard J.: Methods and strategies for overvoltage prevention in low voltage distribution systems with PV. IET Renewable Power Generation 11(2), 2017, 55-64 [http://doi.org/10.1049/IET-RPG.2016.0277].

[3] Janiga K.: A review of voltage control strategies for low-voltage networks with high penetration of distributed generation. Informatyka, Automatyka, Pomiary w Gospodarce i Ochronie Środowiska - IAPGOS 3, 2020, 60-65.

[4] Mahmud N., Zahedi A.: Review of control strategies for voltage regulation of the smart distribution network with high penetration of renewable distributed generation. Renewable and Sustainable Energy Reviews 64/2016, 582-595.

[5] Renewable Energy Sources Act of February 20/2015, Dz. U. 2015 poz. 478

[6] Commission Regulation (EU) 2016/631 of April 14, 2016 establishing the EU network code

[7] Instruction of Distribution Network Operation and Maintenance (IRiESD), PGE Dystrybucja S.A.

[8] PN-EN 50160:2010 Parametry napięcia zasilającego w publicznych sieciach elektroenergetycznych.

[9] PN-EN 50549-1:2019-02 Wymagania dla instalacji wytwórczych przeznaczonych do równoległego przyłączania do publicznych sieci dystrybucyjnych

[10] PN-EN 50438:2014-02 Wymagania dla instalacji mikrogeneracyjnych przeznaczonych do równoległego przyłączania do publicznych sieci dystrybucyjnych niskiego napięcia.

[11] PN-EN 61000-4-30: 2015-05 Kompatybilność elektromagnetyczna (EMC) Część 4-30: Metody badań i pomiarów - Metody pomiaru jakości energii.

[12] Set of requirements for type A power generating modules, including microinstallations, PGE Dystrybucja S.A.

\section{M.Sc. Klara Janiga \\ e-mail: k.janiga @pollub.pl \\ Klara Janiga received M.Sc. degree in electrical engineering (specializing in power engineering) from the Lublin University of Technology (LUT), Poland. She is currently an assistant in the Department of Power Engineering and Ph.D. student at LUT. Her research interest is concentrated on distributed generation, in particular on photovoltaic systems.}

